\title{
Er sykepleierne fortsatt engler?
}

Endringer i helsevesenet gir sykepleierne mindre tid og mulighet til å være der for pasienten når det virkelig trengs.

\section{Forfattere}

Inger Cecilie Frisvoll

Ph.d.-stipendiat

Høgskolen i Molde

\section{Nøkkelord}

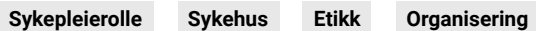

\section{HOVEDBUDSKAP}

En sykepleier er en hvit engel. Et par varme hender. Pasientens advokat. Honnørbetegnelsene er mange. Men består hverdagen av hvite engler med varme hender, som utrettelig argumenterer for pasientens beste?

Sykepleierprofesjonen har søkelys på det etiske. Pasienten er en helhet, ikke summen av sykdommene sine. Å ivareta pasientens verdighet står i høysetet, behovene til pasienten veier tyngst, og pliktetikken skal styre handlingene og valgene våre. Er det rom for det i dagens norske helsevesen? Har vi sykepleiere rom for å la empatien få plass i det systemet vi er satt inn i? Har vi anledning til å ta inn over oss alle situasjonene pasientene og deres pårørende står i? Dersom jeg som sykepleier går inn i rollen som engel med varme hender, alltid parat til å kjempe på barrikadene for alle pasientene jeg møter, hvor lenge vil jeg da holde ut i en sykepleierstilling i det norske helsevesenet?

\section{二 «Pasienten er en helhet, ikke summen av sykdommene sine.»}

\section{Tøffe prioriteringer}

Jeg opplever ikke meg selv som en engel som alltid gjør mitt beste for pasientene jeg har ansvar for. Som sykepleier på legevakten må jeg prioritere mellom herr Olsen med brystsmerter og lille Sara som har kastet opp i et døgn og har sterke magesmerter. Hvem haster det mest for? På den medisinske sengeposten må jeg vurdere om jeg bør ta den hastetelefonen til kommunen før jeg henger opp antibiotika og deler ut middag. Eller kanskje det haster mer å finne de opplysningene legen trenger?

Og er jeg egentlig enig i legens beslutning om at fru Dahl er utskrivningsklar, eller skal jeg prøve å argumentere for at hun bør bli et ekstra døgn? Dilemmaene er mange, og vi sykepleiere kommer stadig opp i situasjoner der vi må velge én pasient fremfor en annen. Vi må prioritere hva som er viktigst og hva som kan vente, og vi må vurdere det ut fra kunnskapen og erfaringsbakgrunnen vår, uavhengig av pasientene.

\section{«Vi sykepleiere kommer stadig opp i situasjoner der vi må velge én pasient fremfor en annen.»}

\section{Et helsevesen i endring}


Stadig oftere tvinges både vi sykepleiere og leger til å skille mellom det vi må gjøre noe med, og det vi kan skyve over på andre. Spesialisthelsetjenesten skal i større grad overføre behandlingsansvar til kommunehelsetjenesten - skillelinjene mellom nivåene forskyver seg gradvis. Samhandlingsreformen gir et tydelig signal om at denne politiske utviklingen er ønsket (1). «Det er til pasientenes beste», sies det $\mathrm{i}$ stortingsmeldingen. Pasientene har det best når de får være nærmest hjemstedet. De skal få behandling der de er, heller enn å være innlagt på sykehus. Veksten i spesialisthelsetjenesten må bremses.

Reformen ble ledsaget av blant annet kutt i sengetallet ved de somatiske sykehusene i Norge. Tall fra Statistisk sentralbyrå viser at da samhandlingsreformen ble implementert fra 2011 til 2012, var det en reduksjon i antall somatiske døgnplasser i norske sykehus på 4,78 prosent. Det tilsvarer 589 færre senger å fordele på pasientene (2). Den gjennomsnittlige liggetiden per innleggelse for pasienter over 80 år - de eldste og sykeste - ble samtidig redusert med nær 12 prosent fra 2011 til 2012 (3, s 53).

Færre senger fører til større pågang på de sengene som finnes. Legene kan da bli presset til å melde pasientene utskrivningsklare til kommunene på et tidligere tidspunkt, og jeg som sykepleier presses til å godta deres vurderinger. Som sykepleier kan jeg også presses til å overtale legene til å melde pasienter utskrivningsklare. I verste fall - og det skjer - er både legen og jeg enige om at det beste for pasienten er å bli et døgn til. Likevel må pasienten meldes til kommunen som utskrivningsklar.

Riksrevisjonens rapport om ressursutnyttelse og kvalitet i helsetjenesten etter innføringen av samhandlingsreformen viser til tall fra Helsedirektoratet (3). Av de pasientene som ble meldt utskrivningsklare, steg andelen reinnleggelser fra 33,9 prosent i 2010 til 44,6 prosent i 2014. Riksrevisjonen påpeker at deres analyser ikke tilsier at denne økningen har noen sammenheng med liggetid før utskrivelse eller antall overliggerdøgn. Likevel er sammenfallet mellom reduksjon i antall døgnplasser og gjennomsnittlig liggetid iøynefallende, samtidig med økningen i andel reinnleggelser.

\section{Preget av nye systemer}

I 1999, da jeg var nyutdannet sykepleier, var sykehusene under fylkeskommunal ledelse med rammeoverføringer fra staten. Dette har endret seg. Sykehusene ble overført til staten i 2002 og drives og ledes i tråd med helseforetaksmodellen. Reformer inspirert av New Public Management (NPM) har satt sitt preg på sektoren (4). Innføringen av innsatsstyrt finansiering med DRG (diagnoserelaterte grupper)poeng i 1997, et pasientklassifiseringssystem som sier hvor mye refusjon de forskjellige sykdommene og diagnosene genererer (5), ble møtt med skepsis før implementeringen.

Lian, forfatter av boken Når helse blir en vare (6), problematiserte innføringen av DRG-systemet allerede i 1994 (7). Hun hevdet at over tid ville systemet føre til at likhets- og rettferdighetsprinsippet kom på vikende front, til fordel for nytte- og effektivitetshensyn samt tanken om bedriftsøkonomisk lønnsomhet i sykehusene. Behovslogikken og pliktetikken ville tape for nytteetikken, en prioritering av pasienter som var økonomisk lønnsomme for sykehusene.

I 2007 fikk Helsedirektoratet utarbeidet en rapport som omhandlet det innsatsstyrte finansieringssystemet (8). De undersøkte blant annet om den aktuelle finansieringsordningen hadde påvirket sykehusledernes og sykehuslegenes prioriteringer av pasienter, noe deltakerne i undersøkelsen mente hadde skjedd. Jeg har også selv, som utøvende sykepleier, sett hvordan helsevesenet har endret seg. Økt lønnsomhet har stadig fått mer oppmerksomhet, blant annet ved å fokusere på den gjennomsnittlige liggetiden for pasientene og produksjonen av DRG-poeng.

\section{Mer kynisk system?}


Jeg ser ikke hele bildet og vil ikke påberope meg å ha svarene, men jeg kan ikke fri meg fra å tenke at den økonomiske tankegangen i stadig større grad trenger seg inn på fagfelter der andre verdier bør stå sterkere enn de økonomiske. De samfunnsmessige endringene er ikke tilrettelagt for englesykepleierne - kanskje heller tvert om. Jeg skal ikke påstå at alt var bedre før, eller at sykepleierne hadde all verdens tid til å stå ved sykesengene og holde pasienten i hånden for 20-30 år siden heller. Jeg har derimot en følelse av at sykepleiere og leger ikke bare har det travelt nå, og på en del områder travlere enn tidligere, men at det også har skjedd en endring i mentaliteten.

\section{«De samfunnsmessige endringene er ikke tilrettelagt for englesykepleierne - kanskje heller tvert om.»}

Har det skjedd en dreining fra at sykepleierne var pasientenes advokater og hvite engler, til at vi nå ser på pasientene som kunder og potensielle inntektskilder? Har vi sykepleiere tatt opp i oss den økonomiske tankegangen og gjort den til en del av oss, og samtidig skjøvet empatien lenger bak i bevisstheten? Eller er det fordi vi, om vi tillater oss å slippe pasientene for nær, ikke vil takle å se hvordan systemet krever at de blir sluset gjennom helsevesenet på mest mulig kostnadseffektiv og strømlinjeformet måte - mest mulig helse for hver krone?

Midt i alt dette finnes de øyeblikkene der en sykepleier er nettopp en engel for pasienten i sengen. De øyeblikkene sykepleieren har rom for - og tid til - å holde pasienten i hånden når det trengs som mest. Det er disse øyeblikkene som gjør at sykepleiere fortsatt er sykepleiere - og engler.

LES OGSÅ: Fra sykehus til sykehjem - hva samhandlingsreformen har ført til

\section{Referanser}

1. Meld. St. 47 (2008-2009). Samhandlingsreformen - Rett behandling - på rett sted - til rett tid. Oslo: Helse- og omsorgsdepartementet; 2009.

2. Statistisk Sentralbyrå. Statistikkbanken: Spesialisthelsetjenesten. Tilgjengelig fra: https://www.ssb.no/statistikkbanken/SelectVarVal/define.asp?SubjectCodeal\&ProductIdal\&MainTableSpesialHelse7\&contentsSenger\&PLanguage $=0 \&$ Qid $=0 \&$ nvlTrue\&mt=0\&pm=\&SessID=13852968\&FokusertBoks=1\&gruppe1=Hele\&gruppe2=Hele\&VS1=HelseInstSom\&VS2=\&CMSSubjectAreahelse\&KortNavnWebspeshelse\&StatVariant=\&Tabstrip-

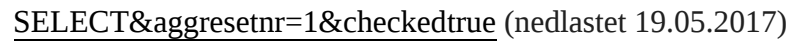

3. Riksrevisjonen. Riksrevisjonens undersøkelse av ressursutnyttelse og kvalitet i helsetjenesten etter innføringen av samhandlingsreformen. Dokument 3:5 (20152016). Oslo: Riksrevisjonen; 2016.

4. Hood C. A Public Management For All Seasons? I: Public Administration. 1991;69(1):3-19.

5. Helse- og omsorgsdepartementet. Oppdragsdokument 2017, Helse Midt-Norge RHF. Oslo; 2017.

6. Lian O.S. Når helse blir en vare: medikalisering og markedsorientering i helsetjenesten. 2. utg. Kristiansand: Høyskoleforlaget; 2007.

7. Lian O.S. Rettferdighetsnormer og fordelingspolitikk: om DRG-finansiering i helsevesenet. I: Norsk statsvitenskapelig tidsskrift. 1994; vol. 10, nr. 4;375-96.

8. Helsedirektoratet. IS-1479 Innsatsstyrt finansiering i helsetjenesten. En vurdering og aktuelle tiltak. Oslo; 2007. 